\title{
Genetic Diversity in a Core Collection Established from the Main Bean Genebank in Spain
}

\author{
Elena Pérez-Vega, Ana Campa, Lucia De la Rosa, Ramón Giraldez, and Juan José Ferreira`
}

\begin{abstract}
Common bean (Phaseolus vulgaris L.) is a traditional crop in many Spanish regions. A major collection of Spanish common bean landraces is maintained at the National Genebank in the Center for Plant Genetic Resources (CRF), Alcala de Henares, Madrid, Spain. A core collection including 200 common bean accessions was established from the CRF collection. We sought to analyze the genetic diversity of this CRF core collection using morpho-agronomic traits, phaseolin seed protein, and a set of 11 molecular markers. Accessions were classified in 65 groups according to their seed phenotype. Seventy-one accessions have appropriate qualities for culinary use as green or snap beans. The four bean growth habits were present among the accessions included in the CRF core collection, with the indeterminate climbing habit (Type IV; 113 accessions) being the most common. Five different phaseolin patterns were found, the most common being type $\mathrm{C}$ (86 accessions), followed by types $\mathrm{T}$ (59 accessions) and S (42 accessions). With the set of molecular markers used, an average number of 6.18 alleles marker ${ }^{-1}$ and an average polymorphism information content marker ${ }^{-1}$ of 0.66 were found. The dendrogram and the principal components analysis developed using the molecular marker data revealed the existence of two main groups of accessions corresponding to the Middle American and the Andean gene pools, respectively, and suggested the existence of some intermediate forms. The possible origin of these putative intermediate forms is discussed. Knowledge of the genetic diversity in the CRF core collection will contribute to improved use and conservation of Spanish bean genetic resources.
\end{abstract}

E. Pérez-Vega, A. Campa, and J.J. Ferreira, Área de Cultivos Hortofrutícolas, SERIDA, 33300 Villaviciosa, Asturias, Spain; L. De la Rosa, Centro de Recursos Fitogenéticos (CRF), INIA, 28040 Madrid, Spain; R. Giraldez, Dep. of Biología Funcional, Univ. of Oviedo, 33006 Oviedo, Spain. Received 11 July 2008. *Corresponding author (jjferreira@serida.org).

Abbreviations: CRF, Center for Plant Genetic Resources; CRF collection, National Spanish common bean collection; MDRK, 'Michigan Dark Red Kidney'; PCA, principal components analysis; PIC, polymorphic information content; SCAR, sequence characterized amplified region; UPGMA, unweighted pair group method with arithmetical averages.

C OMMON BeAn (Phaseolus vulgaris L.) is one of the most important grain legumes for direct human consumption in the world (Broughton et al., 2003). Common bean is mainly harvested fresh as snap bean (pods harvested before the seed development phase) or as dry bean (seeds harvested at complete maturity). The species was domesticated by Middle American and South American cultures (Gepts et al., 1986), and from these regions the species was progressively dispersed worldwide. Two gene pools, Middle American and Andean, have been identified in wild and cultivated common bean associated with these two geographical areas. Variation in the major seed protein phaseolin has contributed significantly to differentiating between these two gene pools. In the Middle American gene pool, the phaseolin type S ('Sanilac') predominates, while the Andean gene pool expresses primarily the phaseolin type $\mathrm{T}$ ('Tendergreen'), followed by the $\mathrm{C}$ and $\mathrm{H}$ types (Gepts et al., 1986; Islam et al., 2002). Morphological differences between the two gene pools were described in domesticated common bean by Singh et al. (1991). Differences between the two gene pools have

Published in Crop Sci. 49:1377-1386 (2009).

doi: 10.2135/cropsci2008.07.0409

(C) Crop Science Society of America

677 S. Segoe Rd., Madison, WI 53711 USA

All rights reserved. No part of this periodical may be reproduced or transmitted in any form or by any means, electronic or mechanical, including photocopying, recording, or any information storage and retrieval system, without permission in writing from the publisher. Permission for printing and for reprinting the material contained herein has been obtained by the publisher. 
also been revealed using different molecular markers such as random amplified polymorphic DNA (Johns et al., 1997; Beebe et al., 2000), amplified fragment length polymorphisms (Tohme et al., 1996; Beebe et al., 2001), or microsatellites (Blair et al., 2006), which explore genome-wide variation, including linkage group B7 where the phaseolin has been mapped (Freyre et al., 1998).

Since introduction to Europe in the 16th century, common bean has been traditionally grown in many Spanish regions. A considerable diversity has been described among the landraces collected in Spain, suggesting that this area could be considered a secondary center of genetic diversity of common bean. Puerta Romero (1961) described wide morphological variation among 296 local varieties and found that those having white seed and dry culinary use were the most common. From phaseolin data, Gepts and Bliss (1988) suggested the presence of the two gene pools in the Iberian Peninsula. Using morphological traits, allozyme markers, and phaseolin variants, Rodiño et al. $(2001,2006)$ and Santalla et al. (2002) described local bean germplasm from the Iberian Peninsula as Middle American or Andean in origin, with the majority of materials having Andean origin. A few inter-gene pool recombinants also were observed.

The National Spanish common bean collection (CRF collection) is maintained at the National Genebank in the Center for Plant Genetic Resources (CRF), Alcalá de Henares, Madrid, Spain. At present, the CRF collection is formed by 2900 accessions (active collection) from which 1250 constitute the base collection. Most of these accessions derive from collecting missions performed in Spain since 1978 or from acquiring accessions from regional genebanks included in the Network of the Spanish Program of Conservation and Utilization of Plant Genetic Resources for Food and Agriculture.

A core collection of 200 bean accessions, established from the CRF collection considering geographical criteria and seed phenotype (De la Rosa et al., 2000), was formed to represent the genetic diversity and genetic structure maintained in the larger germplasm collection (Brown, 1989; van Hintum et al., 2000). Core collections have been proposed as useful tools for the study, utilization, and management of genetic diversity maintained in large germplasm collections (van Hintum et al., 2000). The objective of the present study was to characterize the genetic diversity of the CRF core collection using morpho-agronomic traits, phaseolin seed protein patterns, and DNA markers. Extensive knowledge of this core collection will contribute to improved use and conservation of bean genetic resources from Spain.

\section{MATERIALS AND METHODS Plant Germplasm}

The 200 accessions included in the CRF core collection (De la Rosa et al., 2000) are listed in Table 1. Passport data can be found in the Spanish Plant Genetic Resources Inventory
(http://wwwx.inia.es/webcrf/CR Fing/PaginaPrincipal.asp [verified 29 Mar. 2009]). The international cultivars Sanilac, Michelite, TU, AB136, G2333, Tendergreen, and Michigan Dark Red Kidney (MDRK), and the wild Phaseolus vulgaris accessions G13004 and G23415 were included as reference materials for analysis of the phaseolin and DNA markers. G13004, Sanilac, Michelite, TU, AB136, and G2333 belong to the Middle American gene pool. G23415, Tendergreen, and MDRK belong to the Andean gene pool. The Phaseolus coccineus L. accession V215 was also included in this study.

To characterize morpho-agronomic traits, the 200 accessions were planted in the greenhouse at Villaviciosa, Asturias, Spain, during the spring. One replication, consisting of 10 or 12 plants in a meter-long row for each accession, was planted in a single year. There were two replications (2004 and 2005) in a randomized complete block design.

\section{Morpho-Agronomic Traits}

Core collection accessions were characterized for i) seed phenotype, recorded following the Phaseolus vulgaris descriptor list from IBPGR (1982), including seed coat color (white, cream, yellow, brown, pink, red, purple, black, and gray), pattern (absent, bicolor, constant mottled, speckled, and striped), shape (kidney, oblong, oval, and round), cross-section (flat, oval, and round), size ( $\mathrm{g} 100$ weight $^{-1}$; an average of the $2 \mathrm{yr}$ ), and market class (Voysest, 2000; Santalla et al., 2001); ii) growth habit, according to Singh (1982) as determinate (Type I), indeterminate erect (Type II), indeterminate prostrate (Type III), and indeterminate climbing (Type IV); and iii) pod color (green, yellow, and mottled) and potential culinary use as snap bean, considering pod phenotype (length, fiber amount, fleshiness, and softness) at the R8 stage (Fernández et al., 1985).

\section{Phaseolin Determination}

Phaseolin protein pattern was analyzed in five individual seeds accession $^{-1}$ using the sodium dodecyl sulfate polyacrylamide gel electrophoresis system of Laemmli (1970) as modified by Ferreira et al. (2000). Proteins were extracted from flour samples ( 0.01 to $0.02 \mathrm{~g})$ taken from the raphe end of each seed placed in a buffer solution (62 mM Tris- $\mathrm{HCl} \mathrm{pH} 8.8,2 \%$ (w/v) sodium dodecyl sulfate, $10 \%(\mathrm{v} / \mathrm{v})$ glycerol, and $0.005 \%(\mathrm{w} / \mathrm{v})$ bromphenol blue) for $6 \mathrm{~h}$ at room temperature. The extracts were later reduced with one drop of 2 -mercaptoethanol. The mixture was heat treated $\left(100^{\circ} \mathrm{C}\right)$ for $5 \mathrm{~min}$, centrifuged, and electrophoresis of the supernatant was performed using 1-mm-thick slab gels of 12 or $17 \%(\mathrm{w} / \mathrm{v})$ polyacrylamide. The proteins were visualized using Coomassie Brilliant Blue R.

\section{Molecular Marker Analyses}

Genomic DNA was isolated from bulked young leaves from five to 10 plants accession ${ }^{-1}$, using the Nucleon PhytoPure Genomic DNA Extraction Kit (Amersham Biosciences, Fairfield, CT) following the supplier's instructions. To select a set of molecular markers showing a high polymorphism level, the cultivars TU, MDRK, Michelite, and AB136 were analyzed for 35 microsatellite and sequence characterized amplified region (SCAR) markers previously mapped in the common bean genetic map (Miklas et al., 2000; Blair et al., 2003; Larsen and 
Miklas, 2004). Based on the criteria of at least one marker linkage group $^{-1}$, high polymorphism level, and easy allele identification, 11 markers were selected: SCAR markers SW12 (Singh et al., 2000) and SAP6 (Miklas et al., 2000), and microsatellite markers BMd17, BM184, BM151, BMd45, BM170, BM210, BM172, BM141, and BM175 (Gaitán-Solís et al., 2002; Blair et al., 2003). Amplification of these markers was performed as described by the respective authors. Polymerase chain reaction products corresponding to the SCAR markers were resolved on $2 \%$ agarose gels, stained with ethidium bromide, and visualized under ultraviolet (UV) light. Polymerase chain reaction products corresponding to the microsatellite markers were resolved on $8 \%$ polyacrylamide gels, stained with ethidium bromide, and visualized under UV light. A 100-bp ladder (Amersham Biosciences, Fairfield, CT) and the software PhotoCaptMw (Vilber Lourmat, Marne-la-Vallée, France) were used to measure the size of the amplification products.

\section{Data Analysis}

Molecular marker data were scored as presence (1) or absence (0) of amplified bands. Diversity for each marker was calculated using the polymorphic information content (PIC) according to Anderson et al. (1993): PIC $=1-\sum p_{i j}{ }^{2}$, where $p_{i j}$ is the frequency of the patterns $(j)$ for each marker $(i)$. The data matrix obtained for presence or absence of bands was analyzed by two methods to group the accessions. Principal components analysis (PCA) was performed with NTSYSpc software version $2.11 \mathrm{~V}$ (Rohlf, 2002) and the two principal components were used to visualize the dispersion of the accessions in a graphic. Cluster analysis was performed using unweighted pair group method with arithmetical averages (UPGMA) with NTSYSpc software version $2.11 \mathrm{~V}$. A dendrogram was created with the TREE program of NTSYSpc software version $2.11 \mathrm{~V}$ from the similarity matrix obtained using Jaccard's similarity coefficient (Jaccard, 1928). Significant associations between germplasm groups and morpho-agronomic traits, phaseolin types, and DNA marker variants were identified by means of contingency tests.

\section{RESULTS AND DISCUSSION Morpho-Agronomic Traits and Phaseolin Diversity}

According to seed phenotype, accessions of the CRF core collection were classified in 65 groups (Table 2), 43 of which corresponded to market classes previously described by Voysest (2000) and Santalla et al. (2001). The identified market classes, small white, great northern, canella, cranberry, white kidney, cannellini, hook, or fabada, have high preference and an established reputation among consumers and are traditionally cultivated in several regions in Spain. The remaining 22 groups were designated CRF01 to CRF22. From the green pod characterization it was concluded that 71 accessions (59 green, 9 yellow, and 3 striped) have appropriate qualities for culinary use as snap bean. These accessions were included in 33 seed phenotype groups. With respect to growth habit, indeterminate climbing was the most common (Type IV; 113 accessions),

Table 1. List of common bean accessions included in the Center for Plant Genetic Resources core collection described by De la Rosa et al. (2000). Passport data can be found at http://wwwx.inia.es/webcrf/CRFing/PaginaPrincipal.asp (verified 29 Mar. 2009).

\begin{tabular}{|c|c|c|c|c|c|c|c|}
\hline BGE000993 & BGE003079 & BGE003550 & BGE004434 & BGE011016 & BGE020003 & BGE023679 & BGE026196 \\
\hline BGE001144 & BGE003121 & BGE003554 & BGE004435 & BGE011021 & BGE020030 & BGE024024 & BGE026211 \\
\hline BGE001145 & BGE003122 & BGE003555 & BGE004445 & BGE011023 & BGE020048 & BGE024038 & BGE026222 \\
\hline BGE001452 & BGE003128 & BGE003559 & BGE004452 & BGE011026 & BGE020119 & BGE024699 & BGE027076 \\
\hline BGE001472 & BGE003138 & BGE003562 & BGE004453 & BGE011030 & BGE022070 & BGE025069 & BGE027085 \\
\hline BGE001539 & BGE003139 & BGE003568 & BGE004454 & BGE011037 & BGE022106 & BGE025080 & BGE027961 \\
\hline BGE001856 & BGE003161 & BGE003626 & BGE004459 & BGE011058 & BGE022120 & BGE025085 & BGE027962 \\
\hline BGE002016 & BGE003164 & BGE003645 & BGE004469 & BGE011060 & BGE022129 & BGE025124 & BGE028939 \\
\hline BGE002108 & BGE003165 & BGE003654 & BGE004489 & BGE011062 & BGE022366 & BGE025130 & BGE028940 \\
\hline BGE002116 & BGE003168 & BGE003693 & BGE004496 & BGE011731 & BGE022378 & BGE025142 & BGE028947 \\
\hline BGE002132 & BGE003203 & BGE003696 & BGE004673 & BGE011732 & BGE022476 & BGE025180 & BGE028953 \\
\hline BGE002134 & BGE003208 & BGE003700 & BGE004813 & BGE011735 & BGE022480 & BGE025330 & BGE028958 \\
\hline BGE002152 & BGE003246 & BGE003705 & BGE005439 & BGE011736 & BGE022494 & BGE025739 & BGE028960 \\
\hline BGE002188 & BGE003254 & BGE003746 & BGE005440 & BGE011753 & BGE022504 & BGE025740 & BGE028964 \\
\hline BGE002189 & BGE003261 & BGE003955 & BGE005475 & BGE011758 & BGE022508 & BGE025745 & BGE029568 \\
\hline BGE002196 & BGE003266 & BGE003966 & BGE005484 & BGE011762 & BGE022510 & BGE026146 & BGE029569 \\
\hline BGE002201 & BGE003274 & BGE003997 & BGE005487 & BGE013952 & BGE022512 & BGE026151 & BGE029581 \\
\hline BGE002204 & BGE003283 & BGE004000 & BGE008273 & BGE013953 & BGE022519 & BGE026155 & BGE029586 \\
\hline BGE002207 & BGE003293 & BGE004005 & BGE008274 & BGE013962 & BGE022827 & BGE026158 & BGE029593 \\
\hline BGE002209 & BGE003298 & BGE004010 & BGE008987 & BGE013964 & BGE022831 & BGE026163 & BGE029604 \\
\hline BGE003029 & BGE003404 & BGE004025 & BGE009979 & BGE013965 & BGE022832 & BGE026166 & BGE029629 \\
\hline BGE003037 & BGE003482 & BGE004026 & BGE010387 & BGE013972 & BGE022836 & BGE026169 & BGE029705 \\
\hline BGE003043 & BGE003483 & BGE004031 & BGE010548 & BGE013980 & BGE022837 & BGE026172 & BGE030143 \\
\hline BGE003073 & BGE003484 & BGE004034 & BGE010549 & BGE013981 & BGE023180 & BGE026173 & BGE030453 \\
\hline BGE003074 & BGE003487 & BGE004432 & BGE010957 & BGE019991 & BGE023190 & BGE026186 & BGE030893 \\
\hline
\end{tabular}




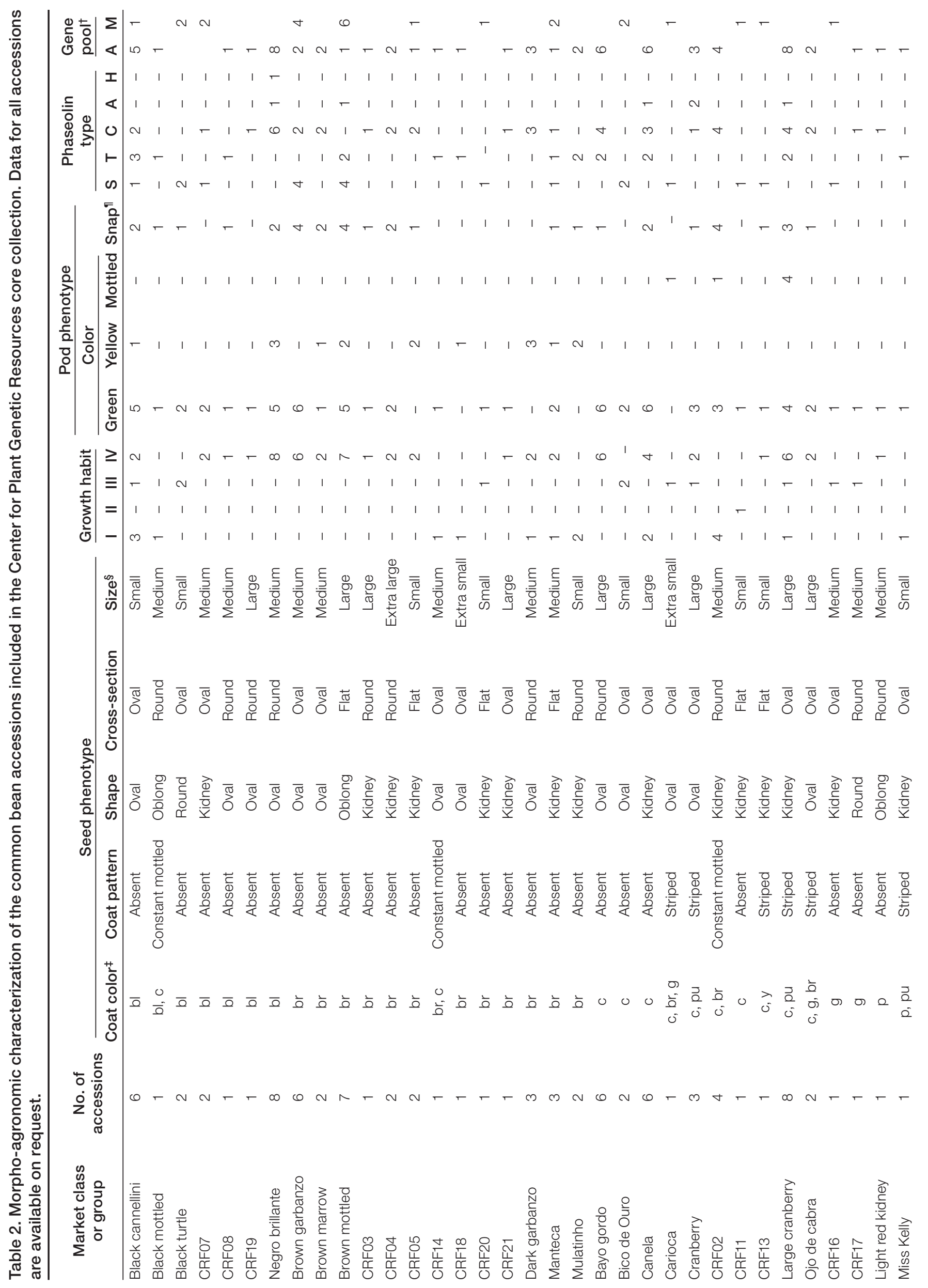




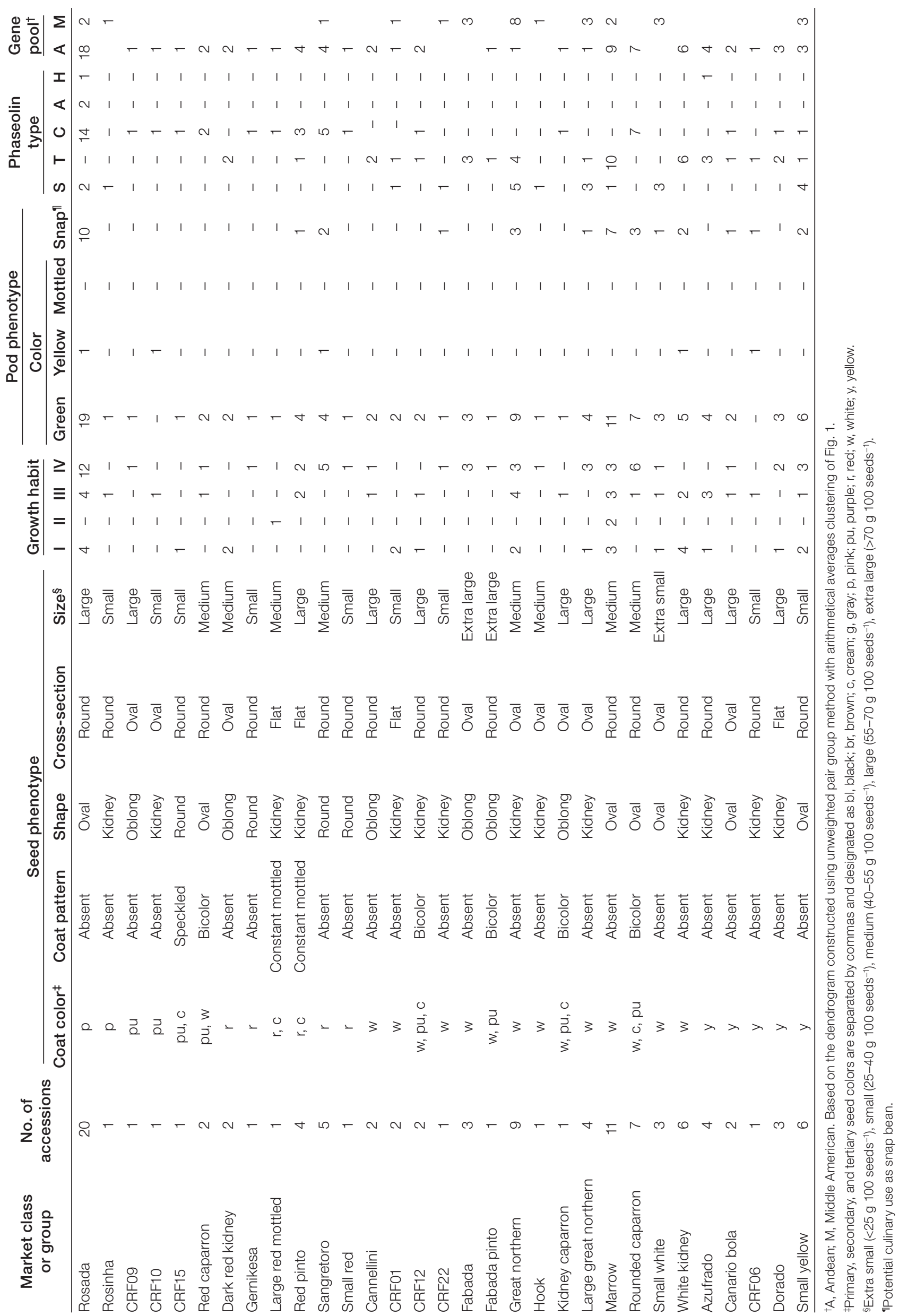


followed by determinate (Type I; 43 accessions) and indeterminate prostrate (Type III; 40 accessions). The indeterminate erect growth habit was relatively scarce (Type II; four accessions). Within-group variation for growth habit was present in 21 seed phenotype groups.

Similar wide diversity for seed phenotype was observed in other bean collections from Spain. Puerta Romero (1961) characterized 296 bean accessions, with white, oblong, and large-seed phenotypes the most common. Santalla et al. (2002) classified 343 accessions in 48 market classes, and Rodiño et al. (2003) grouped 388 accessions in 50 market classes and proposed a core collection with 52 accessions containing 31 market classes. These studies described a higher ratio of white-seeded to color-seeded accessions (163 white:198 colored and 185 white:226 colored, respectively) than observed in the CRF core collection (42 white:158 colored). The potential culinary use of the accessions as snap bean was not evaluated in the previous two studies. For the CRF core collection, 71 of 200 accessions had pod traits corresponding to snap or green bean (Table 2). Puerta Romero (1961) also described a high proportion of snap bean in a Spanish germplasm collection (77 out of 296) and, in many cases (49 out of 296), accessions exhibited dual use as either a snap or dry bean.

Five different phaseolin patterns were observed (Table 2). The most common pattern was phaseolin type C (86 accessions), followed by types T, S, A, and $\mathrm{H}$ with 59, 42, 8 , and 3 accessions, respectively. Within-group variation in phaseolin type was present in 21 seed phenotype groups, of which 11 had phaseolin patterns of both the Middle American and Andean gene pools. Previous phaseolin studies on bean accessions collected in the Iberian Peninsula (Gepts and Bliss, 1988; Santalla et al., 2002) similarly found the C and $\mathrm{T}$ phaseolin patterns as the most frequent.

Table 3. Number of alleles and polymorphism information content (PIC) of the DNA markers used to analyze 200 common bean core accessions and 10 reference materials.

\begin{tabular}{|c|c|c|c|c|c|c|c|c|c|c|c|c|}
\hline \multirow{2}{*}{ Marker } & \multirow{2}{*}{$\begin{array}{c}\text { Marker } \\
\text { type }^{\dagger}\end{array}$} & \multirow{2}{*}{$\begin{array}{l}\text { Linkage } \\
\text { group }\end{array}$} & \multicolumn{9}{|c|}{ Amplification patterns } & \multirow{2}{*}{ PIC } \\
\hline & & & 1 & 2 & 3 & 4 & 5 & 6 & 7 & 8 & 9 & \\
\hline BM141 & SSR & B9 & 185 & 190 & 195 & 218 & 240 & 243 & 245 & 248 & 260 & 0.81 \\
\hline BM151 & SSR & B8 & 136 & 142 & 145 & 148 & 150 & 153 & - & - & - & 0.71 \\
\hline BM170 & SSR & B6 & Null & 200 & 210 & 220 & 230 & 240 & 250 & - & - & 0.79 \\
\hline BM172 & SSR & B3 & 84 & 87 & 89 & 92 & 94 & 96 & 98 & 110 & 119 & 0.75 \\
\hline BM175 & SSR & B5 & 162 & 170 & 173 & 180 & 185 & 190 & 195 & 198 & 200 & 0.76 \\
\hline BM184 & SSR & B11 & 150 & 155 & 157 & 160 & 163 & - & - & - & - & 0.76 \\
\hline BM210 & SSR & B7 & 160 & 165 & 170 & 178 & 183 & 188 & 195 & - & - & 0.70 \\
\hline BMd17 & SSR & B2 & Null & 94 & 105 & 120 & - & - & - & - & - & 0.56 \\
\hline BMd45 & SSR & B1 & 150 & 200 & - & - & - & - & - & - & - & 0.47 \\
\hline SAP6 & SCAR & B10 & Null & 800 & - & - & - & - & - & - & - & 0.44 \\
\hline SW12 & SCAR & B4 & Null & 475 & 550 & 700 & 725 & 750 & $600 / 725$ & $550 / 725 / 750$ & - & 0.56 \\
\hline
\end{tabular}

tSCAR, sequence characterized amplified region; SSR, simple sequence repeat.

抽e SCAR marker SW12 had a maximum of three amplified bands.

\section{Molecular Marker Diversity and Cluster Analysis}

The number of alleles and the PIC values for the nine microsatellite and two SCAR markers are presented in Table 3. Molecular markers SAP6, SW12, BM170, and BMd17 presented null allelles (lack of amplification). All markers had a maximum of one amplified band accession ${ }^{-1}$ except the SCAR marker SW12, which had a maximum of three bands. Rodríguez-Suárez et al. (2007) observed that at least two of the SW12 bands represented closely linked loci. Evidences of heterogeneous accessions were not obtained. The number of alleles varied between two and nine, with an average number of 6.2 alleles marker ${ }^{-1}$. An average PIC value marker ${ }^{-1}$ of 0.66 was found with this set of molecular markers. Although the number of alleles and PIC values for the microsatellites, in most cases, were smaller than those reported by Blair et al. (2006), the level of polymorphism for the markers was relatively high, confirming the wide diversity contained in the CRF core collection. With the set of markers used, 196 different genotypes were identified among the 200 accessions. For other species, such as grapevine (Vitis vinifera L.) cultivars (This et al., 2004) or tomato (Solanum lycopersicum L.) (Bredemeijer et al., 2002), a set of reference cultivars and a minimal standard markers set were proposed for investigating genetic diversity and identifying specific cultivars. Our work similarly describes a set of well-known cultivars and molecular markers whose variants or alleles are easily identified.

The UPGMA cluster analysis differentiated two major groups of accessions (Fig. 1). The group considered Middle American (designated as M) is formed by 60 accessions and includes the Middle American reference materials Sanilac, Michelite, TU, AB136, and G2333, and wild accession G23415. The group considered Andean (designated as

A) is formed by 149 accessions and includes the Andean reference materials Tendergreen, MDRK, and wild accession G13004. The number of accessions assigned to each gene pool within each market class or group according to seed phenotype is indicated in Table 2. Among the 71 accessions having snap bean pod characteristics, 20 were Middle American and 51 were Andean gene pool. In Fig. 1, the presence of four pairs of accessions having an identical combination of marker alleles (Jaccard's genetic distance $=1$ ) is indicated. However, these pairs of accessions showed 
different seed phenotypes: BGE002108 (small yellow) and BGE008273 (brown mottled); BGE022508 (CRF20) and BGE022512 (rosada); BGE003283 (negro brillante) and BGE003645 (dark garbanzo); BGE022476 (rounded caparron) and BGE022494 (brown marrow). Subgroups were not distinguished within the two gene pools, and accessions did not cluster by site of collection.

Table 4 shows the comparison (contingency chisquare tests) between the frequencies of the different morpho-agronomic phenotypes (seed and pod phenotype and growth habit) and phaseolin types in the two groups established by the UPGMA dendrogram. Differences between observed and expected values were highly significant in all cases except for seed shape and culinary use (snap and/or dry vs. only dry). The Andean group possessed a higher number of round-section, largeseeded, and determinate accessions than expected under a random hypothesis. Conversely, a higher number of oval-flat section, small-seeded, and indeterminate accessions were present in the Middle American group. The frequencies of phaseolin types $\mathrm{T}$ and $\mathrm{C}$ were significantly higher in the Andean group, whereas the frequency of type S phaseolin was significantly higher in the Middle American group.

Variation among the three principal components accounted for 25.9, 11.3, and 5.1\% variation, respectively. Figure 2 depicts distribution of the 209 P. vulgaris accessions (the $P$. coccineus accession was not included in this analysis) obtained from the first two principal components (Dim-1 and Dim-2). The two groups established by the cluster analysis are not clearly separated by PCA. Although Andean accessions are located mainly top left, and the Middle American accessions bottom right, 16 accessions showed an intermediate position. These accessions belong to 10 seed phenotypes including the following market classes: brown mottled (BGE002204, BGE026172), canario bola (BGE005439), fabada (BGE010957, BGE011016, BGE027962), negro brillante (BGE003559, BGE022378), red pinto (BGE028939), sangretoro (BGE003138), small red (BGE011058), small yellow (BGE004031, BGE004435, BGE020030), white kidney (BGE022129), and the group CRF1 (BGE024024). Five of them have pods with appropriate characteristic for culinary use as snap bean.

\section{SUMMARY}

The UPGMA and the principal components analyses using molecular marker data revealed the existence of two main groups of accessions in the CRF core collection. The two groups correspond to the Middle American and the Andean gene pools, as supported by the reference materials included in the study, phaseolin types, and different frequencies for growth habit and seed size. The occurrence of two gene pools and characterization

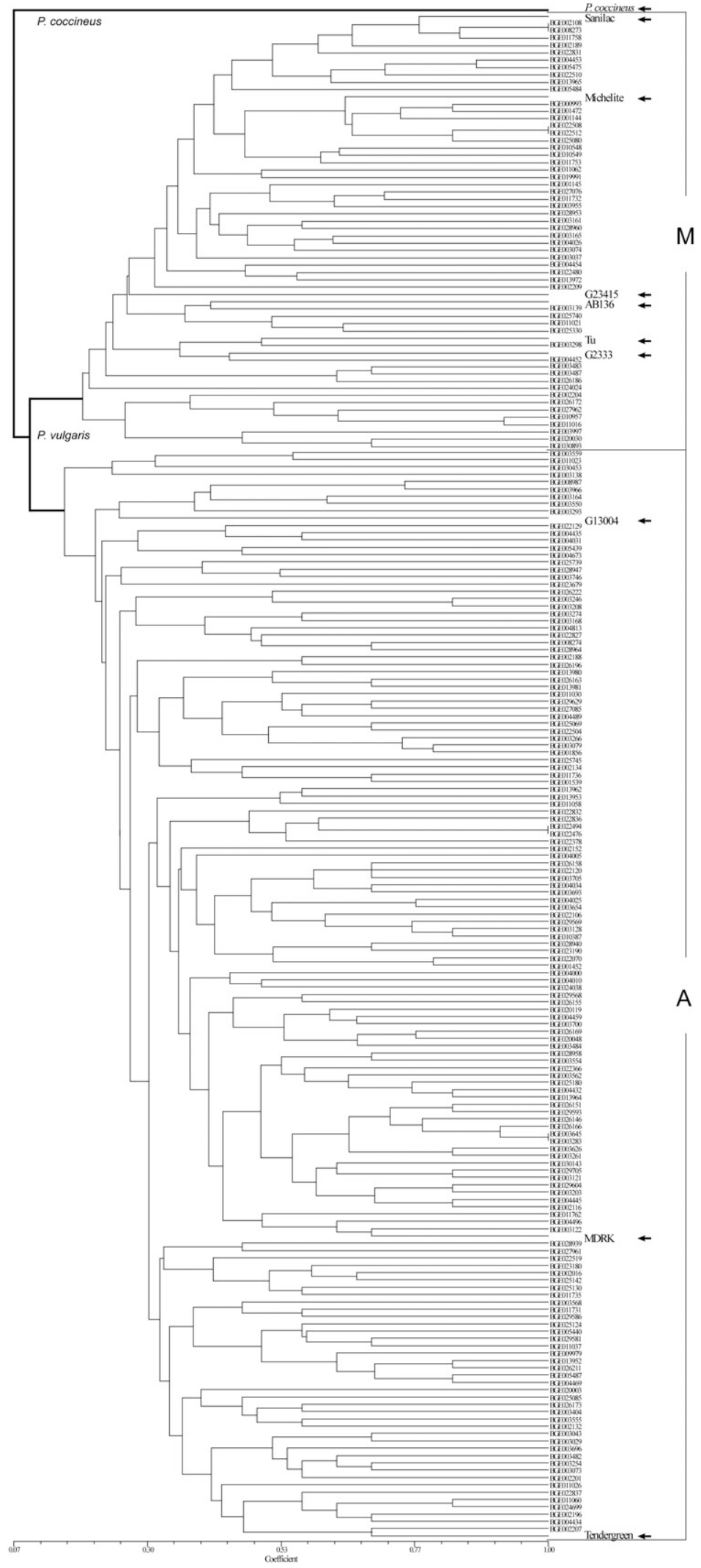

Figure 1. Dendrogram constructed using unweighted pair group method with arithmetical averages clustering, based on Jaccard's distance analysis of a data set of 11 molecular markers, performed with 210 Phaseolus vulgaris accessions (200 accessions of the Center for Plant Genetic Resources core collection and 10 reference cultivars). The Middle American (M) and the Andean (A) reference materials, and the Phaseolus coccineus accession are indicated. MDRK = 'Michigan Dark Red Kidney'. 
Table 4. Comparison between the frequencies of the different morpho-agronomic common bean phenotypes (seed and pod phenotype and growth habit) and phaseolin types in the Middle American and Andean gene pools established by a dendrogram constructed using unweighted pair group method with arithmetical averages clustering.

\begin{tabular}{|c|c|c|c|c|c|c|c|}
\hline \multirow{2}{*}{ Trait } & \multirow{2}{*}{ Main type } & \multicolumn{2}{|c|}{ Andean } & \multicolumn{2}{|c|}{ Middle American } & \multirow{2}{*}{$\chi^{2}$} & \multirow{2}{*}{$P$} \\
\hline & & Observed & Expected & Observed & Expected & & \\
\hline \multirow[t]{4}{*}{ Seed shape } & Round & 10 & 11 & 5 & 4.1 & & \\
\hline & Oval & 54 & 54 & 20 & 20 & & \\
\hline & Oblong & 17 & 15.3 & 4 & 5.7 & & \\
\hline & Kidney & 65 & 65.7 & 25 & 24.3 & 1.80 & ns \\
\hline \multirow[t]{3}{*}{ Seed cross-section } & Round & 88 & 73.7 & 13 & 27.3 & & \\
\hline & Oval & 48 & 57.7 & 31 & 21.3 & & \\
\hline & Flat & 10 & 14.6 & 10 & 5.4 & 21.60 & 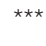 \\
\hline \multirow[t]{5}{*}{ Seed size } & Extra large & 10 & 9.5 & 3 & 3.5 & & \\
\hline & Large & 59 & 44.5 & 2 & 16.5 & & \\
\hline & Medium & 56 & 53.3 & 17 & 19.7 & & \\
\hline & Small & 20 & 35.8 & 29 & 13.2 & & \\
\hline & Extra small & 1 & 2.9 & 3 & 1.1 & 48.45 & 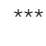 \\
\hline \multirow[t]{2}{*}{ Growth habit } & Determinate & 40 & 31.4 & 3 & 11.6 & & \\
\hline & Indeterminate & 106 & 114.6 & 51 & 42.4 & 11.14 & 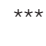 \\
\hline \multirow[t]{2}{*}{ Culinary use } & Snap and/or dry & 51 & 51.8 & 20 & 19.2 & & \\
\hline & Only dry & 95 & 94.2 & 34 & 34.8 & 0.07 & $\mathrm{~ns}$ \\
\hline \multirow[t]{5}{*}{ Phaseolin type } & S & 2 & 30.5 & 40 & 11.5 & & \\
\hline & $\mathrm{T}$ & 49 & 42.9 & 10 & 16.1 & & \\
\hline & C & 82 & 62.5 & 4 & 23.5 & & \\
\hline & A & 8 & 5.8 & 0 & 2.2 & & \\
\hline & $\mathrm{H}$ & 3 & 2.2 & 0 & 0.8 & 127.29 & 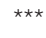 \\
\hline
\end{tabular}

${ }^{\star * \star S i g n i f i c a n t ~ a t ~} 0.001$ probability level.

thereof based on phaseolin and morpho-agronomic traits agrees with previous observations for bean germplasm collections in Spain and elsewhere (Gepts and Bliss 1988; Singh et al., 1991; Santalla et al., 2002; Rodiño et al., 2003, 2006).

The intermediate positions for some accessions in the PCA suggest possible derivation from recombination between the two gene pools. Santalla et al. (2002) and Rodiño et al. $(2003,2006)$ suggested the existence of recombinants between the Middle American and Andean gene pools in accessions from Spain and Portugal. They mainly attributed the presence of such recombinants to natural cross-pollination between common bean of different origins, and concluded that the Iberian Peninsula is a secondary center of genetic diversity for common bean. However, the majority of these putative recombinant materials could have a different origin and the natural occurrence of genetic diversity in the Iberian Peninsula could be lower than indicated by these authors. Accessions maintained in the Network of Spanish Bean Genebanks were obtained in different collecting missions, performed since 1970, including areas where small farmers selected and maintained their own cultivars, considering specific criteria in each area such as seed or pod phenotype, culinary tradition, and cropping system. The cultivation of mixed bean materials (mixed populations for morphological traits) in such areas is practically nonexistent, and the outcrossing rate in the local conditions is extremely low (Ferreira et al., 2000). As indicated by Doré and Varoquaux (2006), the presence of elite cultivars (mainly snap beans) derived from bean breeding programs in Europe, especially in France, began at the end of the 19th century. In Spain the commercialization and distribution of snap bean cultivars has been traditionally more common than those of dry beans. The exchange of dry bean seeds between farmers is very common due to the limited availability of commercial dry bean cultivars. For these reasons, although most accessions present in the Spanish genebanks could be considered as landraces or local germplasm, the possibility for some accessions being originally derived from elite cultivars obtained in breeding programs, including crosses between different gene pools, especially in the case of snap beans, cannot be excluded.

\section{Acknowledgments}

This work was supported by grants RF03-024-C06-03 and RF2007-00014-C04-01 from the Ministerio de Ciencia y Tecnología, Spain. Elena Pérez-Vega was recipient of a salary fellowship from the Caja Rural de Gijón. Ana Campa was recipient of a salary fellowship from the Instituto Nacional de Investigación y Tecnología Agraria y Alimentaria (INIA, Spain). The authors thank S.P. Singh for reviewing the manuscript and J. Fernández Ribacoba for technical assistance in the phaseolin analysis.

\section{References}

Anderson, J.A., G.A. Churchill, J.E. Autrique, S.D. Tanksley, and M.E. Sorrells. 1993. Optimizing parental selection for genetic linkage maps. Genome 36:181-186.

Beebe, S.E., J. Rengifo, E. Gaitán-Solís, M.C. Duque, and J. Tohme. 2001. Diversity and origin of Andean landraces of common bean. Crop Sci. 41:854-862.

Beebe, S.E., P.W. Skroch, J. Tohme, M.C. Duque, F. Pedraza, and J. Nienhuis. 2000. Structure of genetic diversity among common bean landraces of Middle American origin based on correspondence analysis of RAPD. Crop Sci. 40:264-273.

Blair, M.W., M.C. Giraldo, H.F. Buendía, E. Tovar, M.C. Duque, and S.E. Beebe. 2006. Microsatellite marker diversity in common bean (Phaseolus vulgaris L.). Theor. Appl. Genet. 113:100-109. 


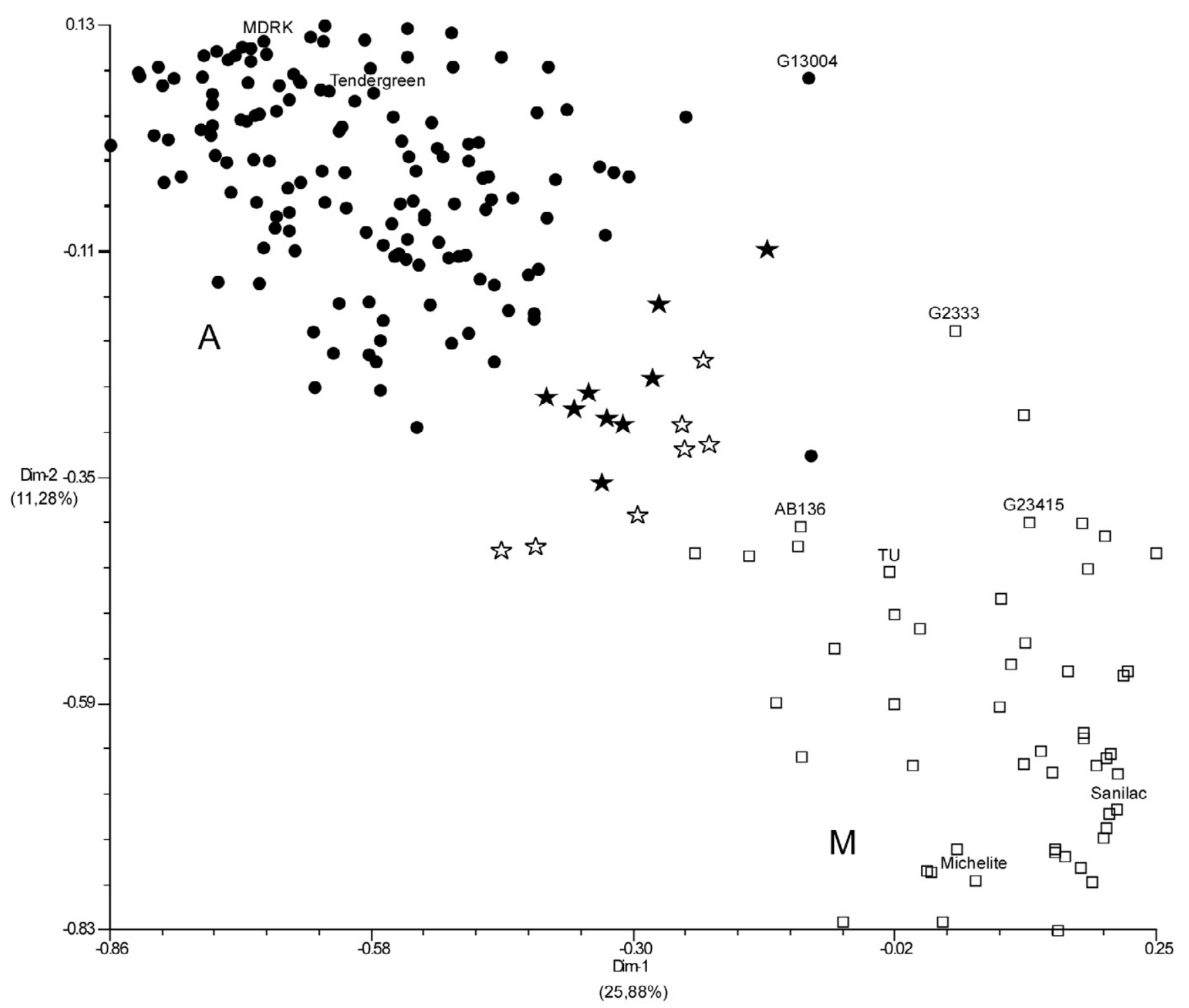

Figure 2. Plot of distribution of 209 Phaseolus vulgaris accessions obtained from Dimensions 1 and 2 (Dim-1 and Dim-2) of a principal components analysis performed with a data set of 11 molecular markers. Middle American (M) and Andean (A) reference materials are indicated. The accessions discriminated in the dendrogram constructed using unweighted pair group method with arithmetical averages clustering as belonging to the Andean or the Middle American gene pools are indicated as filled circles or stars and open squares or stars, respectively. The putative recombinant accessions are indicated by stars. MDRK = 'Michigan Dark Red Kidney'.

Blair, M.W., F. Pedraza, H.F. Buendía, E. Gaitán-Solís, S.E. Beebe, P. Gepts, and J. Tohme. 2003. Development of a genomewide anchored microsatellite map for common bean (Phaseolus vulgaris L.). Theor. Appl. Genet. 107:1362-1374.

Bredemeijer, G.M.M., R.J. Cooke, M.W. Ganal, R. Peeters, P. Isaac, Y. Noordijk, S. Rendell, J. Jackson, M.S. Röder, K. Wendehake, M. Dijcks, M. Amelaine, V. Wickaert, L. Bertrand, and B. Vosman. 2002. Construction and testing of a microsatellite database containing more than 500 tomato varieties. Theor. Appl. Genet. 105:1019-1026.

Broughton, W.J., G. Hernández, M. Blair, S. Beebe, P. Gepts, and J. Vanderleyden. 2003. Bean (Phaseolus spp.); model food legumes. Plant Soil 252:55-128.

Brown, A.H.D. 1989. Core collections: A practical approach to genetic resources management. Genome 31:818-824.

De la Rosa, L., A. Lázaro, and F. Varela. 2000. Racionalización de la colección española de Phaseolus vulgaris L. p. 55-62. In II Seminario de judía de la Península Ibérica. Actas de Asociación
Española de Leguminosas, Villaviciosa (Asturias), Spain.

Doré, C., and F. Varoquaux. 2006. Le haricot: Histoire des varietés cultiveés en France. p. 338-339. In Inst. Scientifique de Recherche Agronomique (ed.) Histoire et amélioration de cinquante plantes cultivées. Collection Savoir-faire, Paris.

Fernández, F., P. Gepts, and M. López. 1985. Etapas de desarrollo en la planta de fríjol. p. 61-78. In M. López et al. (ed.) Frijol: Investigación y producción. PNUD/CIAT, Cali, Colombia.

Ferreira, J.J., E. Alvarez, M.A. Fueyo, A. Roca, and R. Giraldez. 2000. Determination of the outcrossing rate of Phaseolus vulgaris L. using seed protein markers. Euphytica 113:259-263.

Freyre, R., P.W. Skroch, V. Geffroy, A.F. Adam-Blondon, A. Shirmohamadali, W.C. Johnson, V. Llaca, R.O. Nodari, P.A. Pereira, S.M. Tsai, J. Tohme, M. Dron, J. Nienhuis, C.E. Vallejos, and P. Gepts. 1998. Towards an integrated linkage map of common bean: 4. Development of a core linkage map and alignment of RFLP maps. Theor. Appl. Genet. 97:847-856.

Gaitán-Solís, E., M.C. Duque, K.J. Edwards, and J. Tohme. 2002. 
Microsatellite repeats in common bean (Phaseolus vulgaris): Isolation, characterization, and cross-species amplification in Phaseolus ssp. Crop Sci. 42:2128-2136.

Gepts, P., and F.A. Bliss. 1988. Dissemination pathways of common bean (Phaseolus vulgaris; Fabaceae) deduced from phaseolin electrophoretic variability: II Europe and Africa. Econ. Bot. 42:86-104.

Gepts, P., T.C. Osborne, K. Rashka, and F.A. Bliss. 1986. Phaseolin protein variability in wild forms and landraces of the common bean (Phaseolus vulgaris L.): Evidence for multiple centers of domestication. Econ. Bot. 40:451-468.

IBPGR. 1982. Descriptors for Phaseolus vulgaris. Int. Board for Plant Genet. Resources Secretariat, Rome.

Islam, F.M.A., K.E. Basford, R.J. Redden, A.V. Gonzalez, P.M. Kroonenberg, and S. Beebe. 2002. Genetic variability in cultivated common bean beyond the two major gene pools. Genet. Resour. Crop Evol. 49:271-283.

Jaccard, P. 1928. Handbuch biologische Arbeitsmethoden 11:165-202.

Johns, M.A., P.W. Skroch, J. Nienhuis, P. Hinrichsen, G. Bascur, and C. Muñoz-Schick. 1997. Gene pool classification of common bean landraces from Chile based on RAPD and morphological data. Crop Sci. 37:605-613.

Laemmli, U.K. 1970. Cleavage of structural proteins during the assembly of the head bacteriophage T4. Nature 227:680-685.

Larsen, R.C., and P.N. Miklas. 2004. Generation and molecular mapping of a sequence characterized amplified region marker linked with the Bct gene for resistance to Beet curly top virus in common bean. Phytopathology 94:320-325.

Miklas, P.N., R. Delorme, V. Stone, M.J. Daly, J.R. Stavely, J.R. Steadman, M.J. Bassett, and J.S. Beaver. 2000. Bacterial, fungal, and viral disease resistance loci mapped in a recombinant inbred common bean population ('Dorado'/XAN 176). J. Am. Soc. Hortic. Sci. 125:476-481.

Puerta Romero, J. 1961. Variedades de judías cultivadas en España. Monogr. Inst. Nacional de Investigación y Tecnología Agraria y Alimentaria 11. Ministerio de Agricultura, Madrid.

Rodiño, A.P., M. Santalla, A.M. De Ron, and S.P. Singh. 2003. A core collection of common bean from the Iberian peninsula. Euphytica 131:165-175.

Rodiño, A.P., M. Santalla, A.M. González, A.M. De Ron, and S.P. Singh. 2006. Novel genetic variation in common bean from the Iberian Peninsula. Crop Sci. 46:2540-2546.
Rodiño, A.P., M. Santalla, I. Montero, P.A. Casquero, and A.M. De Ron. 2001. Diversity in common bean (Phaseolus vulgaris L.) germplasm from Portugal. Genet. Resour. Crop Evol. 48:409-417.

Rodríguez-Suárez, C., J.J. Ferreira, A. Campa, A. Pañeda, and R. Giraldez. 2007. Molecular mapping and intra-cluster recombination between anthracnose race specific resistance genes in the common bean differential cultivars Mexico 222 and Widusa. Theor. Appl. Genet. 114:713-722.

Rohlf, F.J. 2002. NTSYSpc: Numerical taxonomy system. Version 2.11. Exeter Publishing, Setauket, New York.

Santalla, M., A.M. De Ron, and S.P. Singh. 2001. European bean market classes. p. 79-94. In M. Amurrio et al. (ed.) Catalogue of bean genetic resources. PHASELIEU FAIR 3463-MBGCSIC. Fundación Pedro Barrié de la Maza, Pontevedra, Spain.

Santalla, M., A. Rodiño, and A.M. de Ron. 2002. Allozyme evidence supporting southwestern Europe as a secondary center of genetic diversity for common bean. Theor. Appl. Genet. 104:934-944.

Singh, S.P. 1982. A key for identification of different growth habits of Phaseolus vulgaris L. Annu. Rep. Bean Improv. Coop. 25:92-94.

Singh, S.P., P. Gepts, and D.G. Debouck. 1991. Races of common bean (Phaseolus vulgaris, Fabaceae). Econ. Bot. 45:379-396.

Singh, S.P., F.J. Morales, P.N. Miklas, and H. Terán. 2000. Selection for bean golden mosaic resistance in intra- and interracial bean populations. Crop Sci. 40:1565-1572.

This, P., A. Jung, P. Boccacci, J. Borrego, R. Botta, L. Costantini, M. Crespa, G.S. Dangl, C. Eisenheld, F. Ferreira-Monteiro, S. Grando, J. Ibáñez, T. Lacombe, V. Laucou, R. Magalhães, C.P. Meredith, N. Milani, E. Peterlunger, F. Regner, L. Zulini, and E. Maul. 2004. Development of a standard set of microsatellite reference alleles for identification of grape cultivars. Theor. Appl. Genet. 109:1448-1458.

Tohme, J., D.O. Gonzalez, S. Beebe, and M.C. Duque. 1996. AFLP analysis of gene pools of a wild bean core collection. Crop Sci. 36:1375-1384.

van Hintum, Th.J.L., A.H.D. Brown, C. Spillane, and T. Hodgkin. 2000. Core collections of plant genetic resources. IPGRI Tech. Bull. 3. Int. Plant Genet. Resources Inst., Rome.

Voysest, O. 2000. Mejoramiento genético de fríjol (Phaseolus vulgaris L.). Legado de variedades de América Latina 1930-1999. CIAT, Cali, Colombia. 